\begin{tabular}{|c|c|c|c|c|c|}
\hline JRL & Vol. 13 & No.2 & Hal. 214-221 & $\begin{array}{c}\text { Jakarta, } \\
\text { Desember 2020 }\end{array}$ & $\begin{array}{c}\text { p-ISSN : 2085.38616 } \\
\text { e-ISSN : 2580-0442 }\end{array}$ \\
\hline
\end{tabular}

\title{
GAS HIDROGEN DARI TANDAN KOSONG KELAPA SAWIT MELALUI PROSES SUPERCRITICAL WATER GASIFICATION (SCWG)
}

\author{
Prasetiyadi \\ Pusat Teknologi Lingkungan- BPPT \\ Email : prasetiyadi@bppt.go.id
}

\begin{abstract}
ABSTRAK
Tandan kosong kelapa sawit (TKKS) merupakan biomassa yang memiliki kadar selulosa dan hemi-selulosa tinggi. Besarnya potensi TKKS ini didukung oleh ketersediaannya dengan jumlah sebanyak 11 juta ton per tahun. Selulosa dan hemiselulosa merupakan senyawa yang paling banyak menghasilkan hydrogen dalam proses gasifikasi biomassa. Proses gasifikasi untuk memproduksi gas hydrogen dari limbah tandan kosong kelapa sawit pada suhu $400^{\circ} \mathrm{C}$, waktu tinggal 30 menit dan menggunakan penambahan 10\% air sebagai katalis, menghasilkan 3,9 gram hydrogen per kg TKKS. Dari proses yang telah dilakukan dapat disimpulkan bahwa makin tinggi produksi gas hydrogen makin tinggi pula $\mathrm{CO}_{2}$ yang dihasilkan. Sehingga, perlu dicari kondisi operasi dan jenis katalis yang sesuai untuk digunakan pada proses gasifikasi agar diperoleh hydrogen lebih banyak tetapi $\mathrm{CO}_{2}$ yang dihasilkan lebih sedikit karena $\mathrm{CO}_{2}$ merupakan salah satu gas Rumah Kaca yang harus dikurangi produksinya.
\end{abstract}

Kata kunci: Gasifikasi, hidrogen, limbah, tandan kosong, kelapa sawit 


\title{
HYDROGEN GAS FROM EMPTY BUCHES PALM OIL THROUGH THE SUPERCRITICAL WATER GASIFICATION (SCWG) PROCESS
}

\begin{abstract}
Palm oil empty bunches (OPEFB) is a biomass with high levels of cellulose and hemicellulose. The great potential of this OPEFB is supported by its availability of 11 million tons per year. Cellulose and hemi-cellulose are compounds that produce highest concentration of hydrogen in the biomass gasification process. Gasification process of OPEFB that was carried out at $400^{\circ} \mathrm{C}$, with retention time of about 30 minutes and used the addition of $10 \%$ water as a catalyst produced 3.9 grams of hydrogen per $\mathrm{kg}$ OPEFB. However from the experimental results, it can be concluded that the higher the production of hydrogen gas the higher the $\mathrm{CO}_{2}$ produced. Therefore it is required to find operating conditions and types of catalyst used in the gasification process that result in high concentration of hydrogen but low at $\mathrm{CO}_{2}$ produced as $\mathrm{CO}_{2}$ is one of GHGs that should be reduced.
\end{abstract}

Keywords: Gasification, hydrogen, waste, empty bunches, palm oil 


\section{PENDAHULUAN}

\subsection{Latar Belakang}

Tandan kosong kelapa sawit (TTKS) merupakan salah satu limbah industry yang belum banyak dimanfaatkan, penanganan TTKS saat ini umumnya dibakar atau disebar sebagai mulsa atau penutup lahan dikebun sawit. Dari proses pembakaran TTKS emisi terbanyak yang dikeluarkan adalah gas $\mathrm{CO}_{2}$ dan pada proses pembusukan emisi TTKS gas terbanyak yang terbentuk $\mathrm{CH}_{4}$ dan $\mathrm{CO}_{2}$. Kedua proses penanganan ini menghasilkan gas yang dapat meningkatkan laju pencemaran gas rumah kaca (GRK). Tandan kosong sawit mempunyai kadar air sekitar 60\% (Herawan, T., Rivani, M., 2013), karena kelembapan yang tinggi ini dapat menghambat proses pembakaran (Chang, 2014), sehingga TTKS ini tidak bisa dimanfaatkan langsung sebangai bahan bakar.

Luas lahan sawit Indonesia hingga saat ini mencapai 12,3 juta hektar dengan tingkat produksi minyak sawit sekitar 34,5 juta ton (Anonin 2017). Pengolahan 1 (satu) ton tandan buah segar (TBS) kelapa sawit akan menghasilkan limbah berupa tandan kosong kelapa sawit sebanyak $23 \%$ atau $230 \mathrm{~kg}$ (Susanto at all 2017) atau secara keseluruhan tersedia sekitar 7.9 juta ton per tahun. TKKS merupakan bahan organik / biomassa yang berasal dari tanaman, sebagai hasil fotosintesis. Biomassa ini berasal dari sumber energi matahari yang disimpan dalam bentuk energi kimia, yang dapat dilepaskan ketika ikatan antara molekul karbon, hidrogen dan oksigen yang berdekatan terputus oleh berbagai proses biologis dan termokimia
(McKendry, 2002). Biomas meliputi berbagai bahan organik, yang biasanya terdiri dari; air, selulosa, hemiselulosa, lignin, lipid, protein, pati dan gula sederhana (M. Modell, 1985). Di antara senyawa-senyawa ini, selulosa, hemiselulosa dan lignin adalah tiga komponen utama pada tandan kosong kelapa sawit. Hasil analisa ultimasi komposisi tandan kosong kelapa sawit diperlihatkan ditunjukkan pada table 1 . (Ahmad, 2016)

Tabel 1. Komposisi TTKS

\begin{tabular}{|c|c|c|}
\hline No. & Komposisi & $(\%)$ \\
\hline 1 & Selulosa & 36.78 \\
\hline 2 & Lignin & 21.87 \\
\hline 3 & Hemiselulosa & 27.57 \\
\hline
\end{tabular}

Selulosa dan hemiselulosa merupakan senyawa yang paling banyak menghasilkan hidrogen dalam proses pirolisis/gasifikasi biomassa (WU, et all 2013). Hidrogen merupakan salah satu energy terbarukan yang yang ramah lingkungan. Pemanfaatan tandan kosong sebagai bahan baku untuk memproduksi hydrogen selain akan mengurangi emisi GRK dapat menjadi salah satu potensi sumber energy di Indonesia.

\subsection{Proses Gasifikasi Biomassa}

Gasifikasi merupakan salah satu proses konversi termokimia bahan bakar, seperti batubara, biomassa, dan limbahlimbah. Pada gasifikasi, bahan bakar padat diubah menjadi gas (gas producer) yang dapat dibakar secara langsung sebagai bahan bakar maupun digunakan sebagai bahan baku untuk produksi gas sintetik 
atau hidrogen. Gas yang dihasilkan dari proses gasifikasi umumnya berupa $\mathrm{CO}, \mathrm{H} 2$, $\mathrm{CO}_{2}, \mathrm{CH}_{4}, \mathrm{H}_{2} \mathrm{O}$, dan $\mathrm{N}_{2}$. Selain itu, dalam gasifikasi juga akan dihasilkan bahan organik (tar) dan bahan anorganik $\left(\mathrm{H}_{2} \mathrm{~S}\right.$, $\mathrm{HCl}, \mathrm{NH}_{3}$, logam-logam alkali) serta partikel (Pranoto, 2016).

\subsection{Variabel Utama Dalam Proses Gasifikasi \\ Komposisi dari gas-gas hasil} gasifikasi tergantung dari jenis dan komposisi umpan serta parameter operasi gasifikasi, seperti suhu, tekanan, waktu tinggal dan katalis yang digunakan (gasifying agent) (Perez et all 2015).

Pengaruh dari variable tersebut adalah sebagai berikut :

a. Suhu

Suhu menunjukkan efek signifikan pada proses supercritical water gasification (SCWG) biomassa, terutama ketika tidak ada catalytic converter atau katalis yang kurang efektif (Guo et all, 2007). Bahkan, proses gasifikasi air bertekanan dapat dibagi menjadi tiga kelompok ; suhu tinggi, sedang dan rendah, tergantung pada produk utama dari gasifikasi (Peterson, 2008). Tabel 2 menunjukkan pembagian kelompok suhu proses hidrotermal.

Tabel 2. Pembagian Suhu Hidrotermalberdasarkan Kelompok Suhu (Basu, 2009)

\begin{tabular}{lll}
\hline Batasan Suhu & \multicolumn{1}{c}{ Katalis } & Hasil Produk \\
\hline Tinggi & Tanpa Katalis & Hidrogen \\
$\left(>500^{\circ} \mathrm{C}\right)$ & banyak \\
Sedang & Menggunakan & Hidrogen \\
$\left(\right.$ Tc a $\left.500^{\circ} \mathrm{C}\right)$ & Katalis & banyak
\end{tabular}

W.H.M. Zijm et all 2006 menyampaikan : gas kaya metana diproduksi hingga suhu sekitar. $500^{\circ} \mathrm{C}$, Terjadi pergeseran kuat dari metana menuju hidrogen dan karbon monoksida setelah meningkatkan suhu, suhu yang lebih tinggi mendukung produksi hidrogen.
Grafik hasil perhitungan kesetimbangan gasifikasi selulosa ditunjukkan pada gambar 1

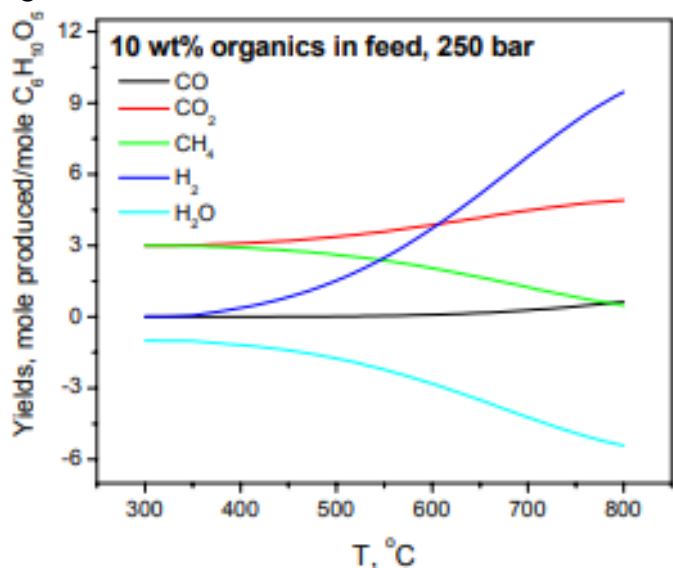

Gambar 1. kesetimbangan gasifikasi selulosa

b. Tekanan

Tekanan pada proses SCWG biomassa memberikan efek yang kompleks (Bühler et al, 2002). Dari hasil observasi laju reaksi radikal bebas berkurang dikarenakan adanya tekanan, sedangkan reaksi ionik meningkat dengan tekanan karena produk ionik dalam kepadatan yang lebih tinggi.

Ketergantungan kepadatan kedua jenis reaksi ini berlawanan satu sama lain (Basu, 2009). Tekanan tinggi mendorong perubahan reaksi uap, tetapi mengurangi laju reaksi dekomposisi (Guo, 2007).

\section{c. Waktu Tinggal}

Waktu tinggal dari sudut pandang termodinamika, biomassa dapat diproses menjadi gas sepenuhnya dalam proses supercritical water (SCW) dengan pembentukan $\mathrm{H}_{2}$ dan $\mathrm{CO}_{2}$. Reaksi gasifikasi dikendalikan oleh kinetika dan beberapa detik diperlukan untuk menyelesaikan proses gasifikasi (Antal, 
2000) gasifikasi $0,1 \mathrm{M}$ glukosa pada $34,5 \mathrm{MPa}$ dan $873 \mathrm{~K}$ dengan berbagai waktu tinggal. Mereka mendapatkan glukosa dapat menjadi dengan cepat dan dengan efisiensi carbon (EC) $100 \%$ dicapai dengan waktu tinggal 28 detik (Lee, et all 2002) juga melaporkan bahwa hasil semua gas tetap hampir konstan pada $973 \mathrm{~K}$, tidak tergantung pada waktu tinggal, kecuali untuk waktu tinggal terpendek 10,4 detik, ketika glukosa 0,6 $\mathrm{M}$ di gasifikasi pada $28 \mathrm{MPa}$. Dengan cara ini, orang dapat berspekulasi bahwa produksi puncak untuk gas pada suhu rendah dapat terjadi dalam waktu tinggal yang lebih besar.

\section{d. Efek dari Katalis \\ Untuk meningkatkan efisiensi ekonomi} SCWG, peningkatan efisiensi gasifikasi, serta penurunan suhu operasi harus dipertimbangkan. Untuk tujuan ini, katalis adalah solusi yang memungkinkan. Namun, katalis untuk SCWG harus berbeda dari yang digunakan dalam gasifikasi konvensional di bawah kondisi operasi tertentu, seperti nilai tekanan tinggi, tujuan (hydrogen produksi, bukan gas sintesis) dan spesifik medium superkritis (Perez, 2015).

Perilaku air di atas titik kritis dan di dekat titik kritis $\left(\mathrm{T}_{\mathrm{c}}=373,946{ }^{\circ} \mathrm{C}, \mathrm{P}_{\mathrm{c}}=\right.$ 220,640 bar) telah dipelajari secara ekstensif (Shaw et all 1991).

Pada suhu rendah katalitik gasifikasi dilakukan pada suhu $350-400 \circ \mathrm{C}$, bahan baku diproses dengan bantuan katalis menjadi gas yang kaya metan. Gasifikasi pada suhu superkritis tinggi dilakukan dalam kisaran $500-700{ }^{\circ} \mathrm{C}$, dengan atau tanpa katalis, dan terutama menghasilkan hidrogen. Pada tahun 1978 biomas diusulkan sebagai bahan baku potensial untuk produksi hidrogen (Antal, 1978) :

Dalam persamaan stoikiometrik ideal ini, selulosa (diwakili sebagai $\mathrm{C}_{6} \mathrm{H}_{10} \mathrm{O}_{5}$ )

$$
\mathrm{C}_{6} \mathrm{H}_{10} \mathrm{O}_{5}+7 \mathrm{H}_{2} \mathrm{O} \rightarrow 6 \mathrm{CO}_{2}+12 \mathrm{H}_{2}
$$

bereaksi dengan air untuk menghasilkan hidrogen dan karbon dioksida.

\subsection{Tujuan Penelitian}

Mengetahui jumlah Hydrogen yang dapat dihasilkan dari tandan kosong (limbah industri pengolahan kelapa sawit / CPO)

\section{METODOLOGI}

\subsection{Bahan dan Alat}

Dalam pelaksanaan penelitian ini bahan yang digunakan adalah tandan kosong (limbah industri pengolahan CPO) yang sudah dikeringkan, kadar air $10 \%$. Bahan ini dihaluskan dengan mesin grinding sehingga menjadi tepung sebelum digunakan. Pada penelitian ini digunakan air sebagai katalis untuk menghasilkan hidrogen. Peralatanyang digunakan dalam penelitian ini adalah:

a. Peralatan utama:

- Micro Reaktor kapasitas $10 \mathrm{ml}$ maksimum suhu $450^{\circ} \mathrm{C} 50 \mathrm{MPa}$ dan mesin pemanas (AKICO) maksimum suhu $500^{\circ} \mathrm{C}$, ditunjukkan pada gambar dibawah ini.

- Gas kromatograf (Shimadzu)

- Gas kromatograf (Yanaco) 
Peralatan utama ditunjukkan pada gambar 2.

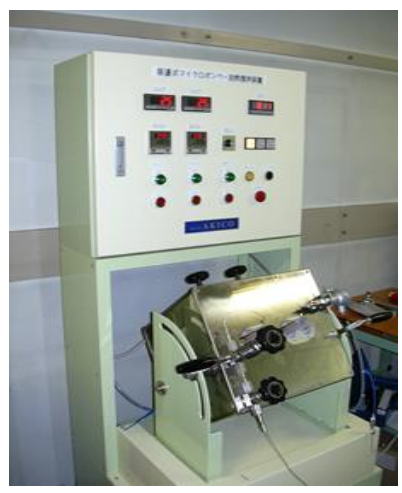

(a)

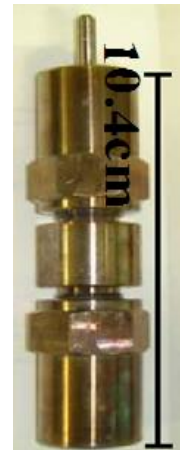

(b)
Gambar 2. Peralatan utama (a) mesin AKOCO (b) Mikro Reaktor

b. Peralatan Penunjang

- Meja dan catok

- Grinding

- Oven

- Timbangan Analitik

- Kunci pas dan kunci momen

- Sikat

- Gas Holder

- Pompa Vakum

- Kipas angin

\subsection{Rancangan Penelitian}

Penelitian ini dilakukan dengan tiga variable suhu yaitu $300^{\circ} \mathrm{C}, 350^{\circ} \mathrm{C}$ dan 400 ${ }^{\circ} \mathrm{C}$, penambahan air dilakukan sebagai katalisator dalam proses yang terjadi didalam reaktor. Tekanan kerja pada penelitian ini tidak ditetapkan secara pasti karena besarnya tekanan akan sangat tergantung dari jumlah bahan, air yang dimasukkan didalam reaktor dan suhu, sedangkan volume reaktor yang digunakan $10 \mathrm{ml}$. Jumlah perbandingan antara bahan dan penambahan air adalah : 0,$2 ; 0,5 ; 1 ; 2$; $5 ; 10$. Sedangkan waktu tinggal selama 30 menit setelah suhu yang diinginkan tercapai.

\subsubsection{Proses pengumpulan data}

Data yang digunakan dalam penelitian ini adalah data hasil percobaan melalui proses gasifikasi yang dilakukan terhadap bahan. Bahan yang sudah disiapkan ditimbang sesuai ukuran kemudian dimasukkan kedalam reaktor dan ditambah sejumlah air, reaktor kemudian dipanaskan dan selama proses berlangsung dilakukan pencatatan ; suhu, tekanan dan waktu tinggalnya. Setelah proses selesai dilakukan pendinginan reaktor, setelah reaktor mencapai suhu kamar, gas yang terbentuk dari hasil gasifikasi ini dimasukkan kedalam gas bag untuk dibawa ke ruang analisa.

\subsubsection{Analisa data}

Untuk menghitung jumlah gas yang dihasilkan dari proses gasifikasi yang dilakukan Reaktor dan mesin pemanas (Akiko) kemudian dianalisa dengan menggunakan gas kromatografi, yang dilakukan sebagai berikut :

- Pada analisa dengan Gas kromatograf (Yanaco) didapat : $\mathrm{H}_{2}$ dan $\mathrm{CH}_{4}$

- Pada analisa dengan Gas kromatograf (Shimadzu) didapat : $\mathrm{O}_{2}, \mathrm{CO}, \mathrm{CH}_{4}, \mathrm{CO}_{2}$, $\mathrm{C}_{2} \mathrm{H}_{4}$ dan $\mathrm{C}_{2} \mathrm{H}_{6}$

Data yang dihasilkan tersebut didapat dalam jumla \% masing-masing gas. 


\section{HASIL DAN PEMBAHASAN}

\subsection{Perhitungan hasil analisa}

Dari hasil analisa data dengan menggunakan gas kromatografi didapat jumlah gas-gas yang dihasilkan dalam satuan persen (\%), dari data tersebut dikonversi dengan berat molekul (BM) dari masing masing gas sehingga didapat hasil seperti ditunjukkan pada tabel berikut:

Kondisi operasi (salah satu contoh perhitungan data) :

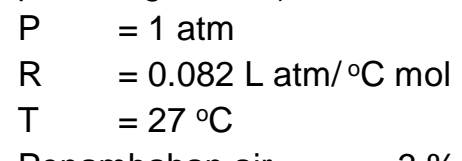

Penambahan air $\quad=3 \%$

Volume penambahan air $=6 \mathrm{ml}$

Berat sample $\quad=2,0087$ gram

$\%$ kandungan air

$=\frac{6}{6+2,008} \times 100 \%=25,0814 \%$

Tekanan awal $=0.25 \mathrm{MPa}$

Tekanan pada suhu $400^{\circ} \mathrm{C}=48.7 \mathrm{MPa}$

Tekanan akhir/ setelah didinginkan $=3.07$ $\mathrm{MPa}$

Selisih tekanan $=3.07-0.25=2.82 \mathrm{Mpa}$

total gas yang dihasilkan $=$

\section{$2.82 \mathrm{Mpa}$}

$0.1 \times 0,01 / 27^{\circ} \mathrm{C} / 0.082 \mathrm{~L} \mathrm{~atm} /{ }^{\circ} \mathrm{C} \mathrm{mol}$ $=0.127371 \mathrm{~mol}$

Jumlah $\mathrm{mol}=1 \mathrm{~atm} \times 0.3 \mathrm{ml} / 1000 / 0.082 \mathrm{~L}$ atm $/{ }^{\circ} \mathrm{C} \mathrm{mol} / 27^{\circ} \mathrm{C}$

$$
=0,000135501 \mathrm{~mol}
$$

Dibandingkan dengan jumlah sampel

$=0.127371 \mathrm{~mol} / 0,000135501 \mathrm{~mol}$

$=940$

$\mathrm{H}_{2}(\mathrm{ml} /$ area $)=2.84249689397645 \mathrm{E}-07$
Area A1 dan Area A2 didapat dari hasil analisa Gas cromatografi

$\mathrm{ml} 1=(\mathrm{ml} /$ area $) \times$ area $\mathrm{A} 1 \times 940$

$=4.75 \mathrm{E}+01$

$\mathrm{ml} 2=(\mathrm{ml} /$ area $) \times$ area $\mathrm{A} 2 \times 940$

$$
=44,4
$$

$\mathrm{ml}$ rata-rata $=(\mathrm{ml} 1+\mathrm{ml} 2) / 2$

$$
=45,95
$$

$\mathrm{ml} \quad=\mathrm{ml}$ rata-rata $-\mathrm{ml} 2$

$=1,5249$

$\mathrm{mol}=\frac{1 \mathrm{~atm} \times \mathrm{ml} \text { rata-rata }}{\left(1000 \times 0.082 \mathrm{~L} \mathrm{~atm} /{ }^{\circ} \mathrm{C} \mathrm{mol} \times 300^{\circ} \mathrm{K}\right.}$

$$
=0,001867832
$$

$\%$ volume $\mathrm{H}_{2}=\mathrm{ml} 1 /$ total $\mathrm{ml} 1 \times 100$ $=1.18 \mathrm{E}+01$

Berat Mol (BM) $\mathrm{H}_{2}=2$

Berat gas dihasilkan $=2 \times 0,001867832$

$$
=0.003736
$$

$\mathrm{H}_{2}$ g/g sample = Berat gas dihasilkan /

Berat sample

$=0.003736 / 2,0087$ gram

$=0.00186$

$=1,86 \mathrm{~g} / \mathrm{kg}$ sample

Dengan cara yang sama perhitungan

\begin{tabular}{|c|c|c|c|c|c|}
\hline Gas & $\mathrm{ml}$ & BM & $\begin{array}{l}\text { Berat Gas } \\
\text { (gг) }\end{array}$ & $\begin{array}{c}g / g \\
\text { sample }\end{array}$ & $\begin{array}{l}\mathrm{g} / \mathrm{kg} \\
\text { sample }\end{array}$ \\
\hline H2 & 45.95 & 2 & 0.003736 & 0.0밍 & 1.86 \\
\hline 02 & 6.971 & 32 & 0.009069 & 0.00451 & 4.51 \\
\hline CD & 1.47 & 28 & 0.001674 & 0.00083 & 0.83 \\
\hline СH4 & 24.6 & 伯 & 0.016002 & ०.००797 & 7.97 \\
\hline टव2 & 306.8 & 44 & 0.548818 & 0.27322 & 273.22 \\
\hline [2:H4 & 0.196 & 28 & 0.000223 & ०.००णा1 & 0.11 \\
\hline С2НБ & 11.18 & 30 & 0.013636 & 0.00679 & 6.79 \\
\hline N2 & 13.4 & 28 & 0.015248 & 0.00759 & 7.59 \\
\hline
\end{tabular}
juga dilakukan terhadap gas-gas lain yang dihasilkan dan perinciannya ditunjukkan pada tabel 3 .

Tabel 3. Perhitungan hasil analisa 
Perhitungan dan pengulangannya untuk masing-masing sampel juga dilakukan untuk suhu: $300{ }^{\circ} \mathrm{C}, 350^{\circ} \mathrm{C}$ dan $400{ }^{\circ} \mathrm{C}$ dengan persen penambahan air : 0,$2 ; 0,5 ; 1 ; 2 ; 5$ dan 10. Hasil perhitungan gas yang dianalisa dari hasil perrcobaan masing masing ditunjukkan pada tabel 4 .

\subsection{Pembahasan}

Dari hasil percobaan gas $\mathrm{H} 2$ dapat terbentuk baik proses dengan suhu 300 ${ }^{\circ} \mathrm{C}, 350{ }^{\circ} \mathrm{C}$ maupun $400{ }^{\circ} \mathrm{C}$, akan tetapi jumlahnya berbeda pada tiap-tiap kondisi tersebut. Perbandingan jumlah produksi gas $\mathrm{H}_{2}$ ditunjukkan pada gambar 3 berikut:

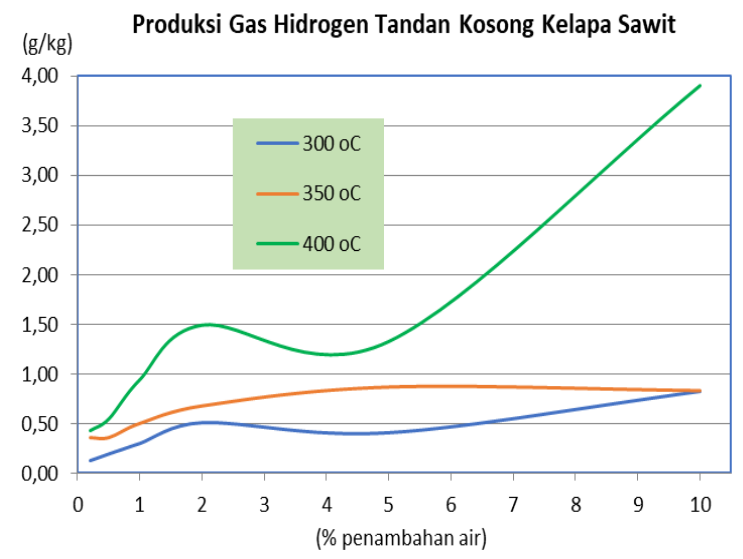

Gambar 3. Perbandingan jumlah produksi gas $\mathrm{H}_{2}$

Dari gambar 3 terlihat bahwa dengan penambahan katalis (air) yang sama, makin tinggi suhu proses, gas $\mathrm{H}_{2}$ yang dihasilkan makin banyak. Jumlah terbesar gas $\mathrm{H}_{2}$ yang dapat dihasilkan pada penelitian ini adalah dengan kondisi operasi suhu $400{ }^{\circ} \mathrm{C}$ dan penambahan air $10 \%$ yaitu $3,9 \mathrm{~g} / \mathrm{kg}$ bahan (tandan kosong).

Penelitian yang dilakukan dengan mesin AKIKO ini menghasilkan jumlah produksi $\mathrm{H}_{2}$ tertinggi pada suhu $400{ }^{\circ} \mathrm{C}$ dengan penambahan air $10 \%$. Pada kondisi ini juga terbentuk gas $\mathrm{CO}_{2}$ yang jumlahnya 305,95 g/kg. Seperti ditunjukkan pada gambar 4 berikut.

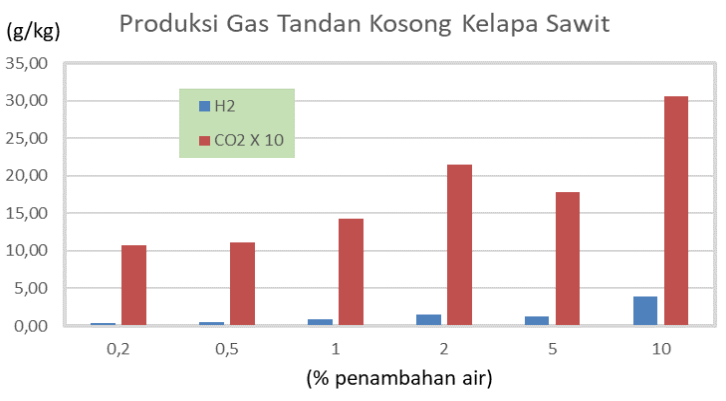

Gambar 4. Jumlah produksi gas $\mathrm{H}_{2}$ dan $\mathrm{CO}_{2}$.

Jika dilihat dari gambar 4 penambahan jumlah air dapat meningkatkan produksi gas $\mathrm{H}_{2}$. dan pada ada kondisi ini produksi gas $\mathrm{CO}_{2}$ yang terbentuk juga lebih besar.

Keterbatasan percobaan dengan menggunakan mesin AKIKO ini adalah sehu hanya diijinkan hanya sampai $400{ }^{\circ} \mathrm{C}$. sedangkan menurut W.H.M. Zijm et all 2006 gas $\mathrm{H}_{2}$ baru akan terlihat dengan produksi tinggi pada suhu diatas $600{ }^{\circ} \mathrm{C}$, jumlah katalis (air) juga secara umum berpengaruh terhadap produksi gas lain seperti; $\mathrm{CO}, \mathrm{CH}_{4}$, $\mathrm{C}_{2} \mathrm{H}_{4}$ dan $\mathrm{C}_{2} \mathrm{H}_{6}$ seperti ditunjukkan pada gambar 5 .

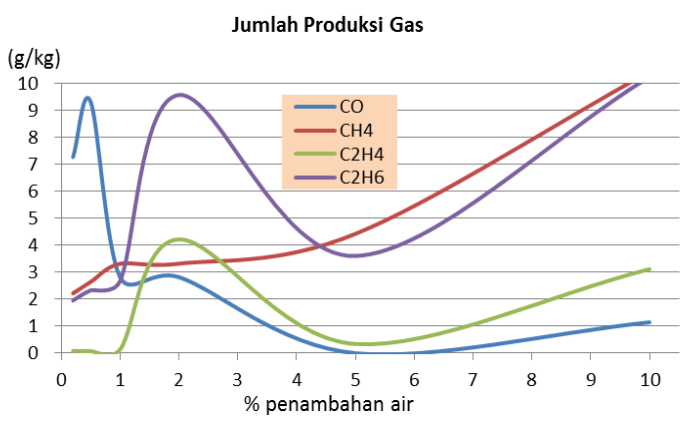

Gambar 5. Jumlah produksi gas lainnya

Dari gambar 5 diketahui bahwa produksi gas $\mathrm{CO}, \mathrm{C}_{2} \mathrm{H}_{4}$ dan $\mathrm{C}_{2} \mathrm{H}_{6}$ antara penambahan air 0,2 sampai $5 \%$ bervariasi naik dan turun dan naik kembali setelah penambahan air 
diatas $5 \%$. Sementara produksi gas $\mathrm{CH}_{4}$ terus meningkat dengan semakin banyaknya penambahan jumlah air.

\subsection{Beberapa Temuan}

Dari hasil pengamatan selama berjalannya penelitian didapat temuan sebagai hal berikut :

- Limbah dari proses gasifikasi ini berupa padatan dan cairan dimana $\mathrm{pH}$ nya rendah yaitu sekitar 4 .

- Limbah sisa olahan proses gasifikasi ini mempunyai sifat lengket dan sering menyebabkan tersumbatnya pipa saluran gas, makin tinggi suhu yang digunakan limbah makin lengket dan sulit dibersihkan.

- Sebagian limbah olahan proses gasifikasi ini masih dapat dibakar setelah dikeringkan

\section{KESIMPULAN}

1. Dari hasil percobaan pengolahan limbah tandan kosong kelapa sawit dengan proses gasifikasi di dekat titik kritis air dengan kondisi operasi suhu $300^{\circ} \mathrm{C}, 350^{\circ} \mathrm{C}$ dan $400^{\circ} \mathrm{C}$ produksi hydrogen terbesar terjadi pada suhu $400^{\circ} \mathrm{C}$ dan penambahan air $10 \%$. Pada kondisi ini menghasilkan 3,9 gram hydrogen per $\mathrm{kg}$ tandan kosong.

2. Selain menghasilkan gas $\mathrm{H}_{2} 3,9 \mathrm{gr} / \mathrm{kg}$ tandan kosong, proses yang dilakukan juga menghasilkan gas $\mathrm{CO}_{2}$ sebanyak $305.95 \mathrm{~g} / \mathrm{kg}$ tandan kosong.

3. Dari proses yang dilakukan dengan menggunakan suhu operasi $300-400$ ${ }^{\circ} \mathrm{C}$, makin tinggi produksi gas $\mathrm{H}_{2}$ makin tinggi $\mathrm{CO}_{2}$ yang dihasilkan.

4. Pengolahan limbah tandan kosong kelapa sawit dengan proses gasifikasi pada suhu rendah menhgasilkan lebih banyak gas $\mathrm{CO}_{2}$. Untuk menghasilkan gas hidrogen yang lebih tinggi harus dilakukan dengan dengan suhu tinggi

\section{Ucapan Terimakasih}

Penulis mengucalpan terimakasih kepada :

1. Prof. Kardono (Pusat Teknologi Lingkungan BPPT) yang telah memberikan kesempatan untuk melaksanakan penelitian ini.

2. Prof. Tatsuya Hasegawa ( Direktur Lembaga Eco Topia Universitas Nagoya) yang telah memberikan fasilitas, pengarahan dan bimbingan dalam penelitian ini.

\section{DAFTAR PUSTAKA.}

Antal, M.J.1978 : Energy from Biomass and Waste, D.L. Class. Chicago: 495, 1978

M. Modell, 1985 "Gasification and liquefaction of forest products in supercritical water," in Fundamentals of thermochemical biomass conversion, Springer, 1985, pp. 95-119.

Shaw, R.W., T.B. brill, A.A. Clifford, 1991. E.U. Franch: Supercritical Water-a Medium for Chemistry, Chem. Eng.News 69:26, 1991

M. J. Antal, S. G. Allen, D. Schulman, X. Xu, and R. J. Divilio, 2000 "Biomass gasification in supercritical water, " Ind. Eng. Chem. Res., vol. 39, no. 11, pp. 4040-4053, 2000.

P. McKendry, 2002 "Energy production from biomass (part 1): overview of biomass," Bioresour. Technol., vol. 83, no. 1, pp. 37-46, 2002.

W. Bühler, E. Dinjus, H. J. Ederer, A. Kruse, and C. Mas, 2002 "lonic reactions and pyrolysis of glycerol as competing reaction pathways in near- and supercritical water," J. 
Supercrit. Fluids, vol. 22, no. 1, pp. 37-53, 2002.

I.-G. Lee, M.-S. Kim, and S.-K. Ihm, 2002 "Gasification of glucose in supercritical water," Ind. Eng. Chem. Res., vol. 41, no. 5, pp. 1182-1188, 2002.

W.H.M. Zijm at all 2006 "Gasification Of Biomass In Supercritical Water" Wöhrmann Print Service, Zutphen, The Netherlands (c) Biljana Potic, Enschede, The Netherlands, 2006. ISBN 90-365-2367-2

L. GUO, Y. LU, X. ZHANG, C. JI, Y. GUAN, and A. PEI, 2007 "Hydrogen production by biomass gasification in supercritical water: A systematic experimental and analytical study," Catal. Today, vol. 129, no. 3-4, pp. 275-286, 2007.

Peterson, F. Vogel, R. P. Lachance, M. Fröling, M. J. Antal Jr, and J. W. Tester, 2008 "Thermochemical biofuel production in hydrothermal media: a review of sub-and supercritical water technologies," Energy Environ. Sci., vol. 1, no. 1, pp. 32-65, 2008.

P. Basu and V. Mettanant, 2009 "Biomass Gasification in Supercritical Water-A Review," Int. J. Chem. React. Eng., vol. 7, no. 1, 2009.

Herawan, T., Rivani, M., 2013, Pemanfaatan Limbah Padat Kelapa Sawit untuk Produksi Green Product. Prosiding Pertemuan Teknis Kelapa Sawit 2013. JCC Jakarta 7-9 Mei 2013. ISBN 978602-7539-16-7, 181- 190.

Wu, Chunfei dkk. 2013. "Pyrolysis/Gasification of Cellulose, Hemicellulose and Lignin for Hydrogen Production in the Presence of Various Nickel-Based Catalysts". Fuel 106: 697 - 706
Chang, S.H., 2014, "An Overview of Empty Fruit Bunch from Oil Palm as Feedstock for Biooil Production" Biomass \& Bioenergy, 1-8

Lachos-Perez D, Juliana M. Prado, TorresMayanga $P$, Tânia ForsterCarneiro, M. Angela A. Meireles, 2015 "Supercritical Water Gasification of Biomass for Hydrogen Production: Variable of the Process" Food and Public Health 2015, 5(3): 92-101

Ahmad M. Fuadi, Heri Pranoto 2016 "Pemanfaatan Limbah Tandan Kosong Kelapa Sawit Sebagai Bahan Baku Pembuatan Glukosa" Journal Chemica Volume 3, Nomor 1, Juni 2016, 1-5 ISSN: 2355-8776

Anonim Statistik Kelapa Sawit Indonesia 2017 Katalog : 5504003 BADAN PUSAT STATISTIK.

Joko Prayitno Susanto, Arif Dwi Santoso dan Nawa Suwedi, 2017 "Perhitungan Potensi Limbah Padat Kelapa Sawit untuk Sumber Energi Terbaharukan dengan Metode LCA" Jurnal Teknologi Lingkungan Vol. 18, No 2, Juli 2017, 165-172 165

Adjar Pratoto , Slamet Raharjo, 2008 "Gasifikasi-uap Biomassa untuk Menghasilkan Hidrogen - Simulasi dengan Model Keseimbangan" Conference Paper . November 2008.

https://www.researchgate.net/publi cation/319998505 ISBN 978-97918839-0-0 diunduh 24 Sep 2019

Zijm at all "Gasification Of Biomass In

Supercritical Water" Wöhrmann Print Service, Zutphen, The Netherlands (C) Biljana Potic, Enschede, The Netherlands, 2006. ISBN 90-365-2367-2 